\title{
JAVASLAT A PÁLYAORIENTÁCIÓ TÉMAKÖRÉBEN \\ GYAKORI FOGALMAK RENDSZEREZÉSÉRE
}

\section{Szerző:}

Mező Ferenc (PhD.)

Eszterházy Károly Katolikus Egyetem

(Magyarország)
Lektorok:

\author{
Lubinszki Mária (PhD.) \\ Miskolci Egyetem \\ (Magyarország) \\ Zuzana Nagyová Lehocká (PhD.) \\ Univerzita Konstantína \\ Filozofa v Nitre (Szlovákia)
}

...és további két anonim lector

Szerző e-mail címe:

ferenc.mezo1@gmail.com

Mező Ferenc (2021): Javaslat a pályaorientáció témakörében gyakori fogalmak rendszerezésére. Különleges Bánásmód, 7. (4). 7-19. DOI 10.18458/KB.2021.4.7

\begin{abstract}
Absztrakt
A magyar nyelvben több fogalom is létezik a pályaorientációval kapcsolatban, de jelentésük és egymáshoz való viszonyuk néha nem tűnik elég egyértelműnek. Jelen dokumentum: a) kiemeli, hogy ezek találati száma eltérő a Google, a MATARKA és az EPA adatbázisokban való keresések esetében is, b) megpróbálja megtalálni a különböző találatok számának okait, c) javasol egy lehetséges megoldást e fogalmak rendszerezésével kapcsolatban.
\end{abstract}

Kulcsszavak: pályaorientáció, fogalmak

Diszciplína: pszichológia, pedagógia

\section{Abstract \\ A PROPOSAL TO SYSTEMATIZE FREQUENTLY CONCEPTS \\ IN THE FIELD OF CAREER GUIDANCE}

In the Hungarian language, there are more concepts in connection with career guidance, but their meaning and relation with each other sometimes seem not clear enough. The present paper: a) highlights that their hits numbers are different in the cases of seeking in Google, MATARKA, and EPA databases too, b) tries to find the causes of its different hits numbers, c) suggests a possible solution for systematizing of these concepts.

Keywords: career guidance, concepts

Discipline: psychology, pedagogy 
A tág értelemben vett pályaválasztás témakörével kapcsolatban többféle (tartalmukban, szemléletükben hol egymást átfedő, hol egymástól lényegesen különböző) kifejezéssel is találkozhatunk:

a) a hazai köznyelvben,

b) szakirodalmakban (például: Szatmáriné, 1999, Ritoók, 2006, 2008 Olteanu, 2015, 2019a,b, Mező K., 2015, Zachár, 2005, 2021, Zakar, 1988, 2016(is), Borbély-Pecze, 2010a,b, Borbély-Pecze, Gyöngyösi és Juhász, 2013; Répáczki, 2015; Tudlik, 2019),

c) jogban - lásd: 2019. évi LXXX, 112. § (1) törvény a szakképzésről. De megjegyezzük, hogy a nemzeti köznevelésről szóló 2011. évi CXC törvény $62 . \S(1) / 1$ pontja szerint a pedagógusok kötelessége különösen, hogy tanítványai pályaorientációját folyamatosan irányítsa, ám e törvény nem definiálja a pedagógusok számára, hogy mit értsenek pályaorientáción.

d) a nemzetközi szakirodalomban is Jackson, 2013; Hawthorn, 1991, Watts, 2009, UNESCO, 2002).

A következőkben - a teljesség igénye nélkül bemutatásra kerül néhány az említett kifejezések közül, megtörténik ezek online kereső felületek lekérdezésével végzett gyakorisági elemzése, és az elemzés eredményeinek lehetséges magyarázata. Ezek alapján egy olyan javaslatot is tartalmaz a tanulmány, ami a használatban lévő pályaválasztással kapcsolatos kifejezések meghatározásának egy lehetséges rendszerére épül.

\section{Pályaválasztással kapcsolatos kifejezések: gyakoriságok és lehetséges okok}

$\mathrm{Az}$ 1. táblázat mutat be egy csokorra valót a pályaválasztással kapcsolatos kifejezések köréből (a teljesség igénye nélkül, mintegy demonstrációs jelleggel). Ezek alkalmazásának gyakorisága (ami elterjedtségükre utal) szignifikánsan különbözik egymástól mind a Google (ezer darabra kerekített értékekkel számolva: $\chi^{2}=863,064 ;$ df $=9 ; \mathrm{p}<$ 0,001), mind a magyar folyóiratok tartalom-jegyzékeinek kereshető adatbázisában található címek darabszáma (MATARKA, web: www.matarka.hu $\left(\chi^{2}=590,123 ;\right.$ df $\left.=9 ; \mathrm{p}<0,001\right)$, mind az Elektronikus Periodikai Adatbázis teljes szövegben történő keresést lehetővé tevő adatbázisa (www.epa.oszk.hu - ezer darabra kerekített értékekkel számolva: $\left.\chi^{2}=26,000 ; \mathrm{df}=4 ; \mathrm{p}<0,001\right)$ szerint is (lásd: 1. táblázat és 1. ábra).

1. táblázat: Pályaválasztáshoz kapcsolódó kifejezések gyakorisága (db). Forrás: a Szerző

\begin{tabular}{|c|c|c|c|}
\hline Kifejezés & $\begin{array}{l}\text { Google } \\
\text { (db) }\end{array}$ & $\begin{array}{r}\text { Matarka:b } \\
\text { cikkek } \\
\text { címében }(\mathrm{db})\end{array}$ & $\begin{array}{r}\text { EPA:c } \\
\text { keresés teljes } \\
\text { szövegben (db) }\end{array}$ \\
\hline pályaválasztás & 194000 & 128 & 2987 \\
\hline életpálya-tanácsadás & 94700 & 15 & 2237 \\
\hline pályaválasztási tanácsadás & 63000 & 36 & 419 \\
\hline karrier tanácsadás & 25100 & 0 & 178 \\
\hline szakmai orientáció & 13200 & 2 & 243 \\
\hline pályatanácsadás & 9290 & 6 & 131 \\
\hline életpálya-tervezés & 4150 & 4 & 12545 \\
\hline életút-támogató pályaorientáció & 1070 & 2 & 56 \\
\hline továbbtanulási tanácsadás & 847 & 0 & 26 \\
\hline pályafejlődési tanácsadás & 504 & 1 & 27 \\
\hline élethosszig tartó pályaorientáció & 444 & 1 & 19 \\
\hline életpálya-menedzselés & 247 & 0 & 1274 \\
\hline pályaorientáció & 108 & 58 & 817 \\
\hline életút-támogató tanácsadás & 87 & 0 & 5 \\
\hline pálya tájékoztatás & 4 & 0 & 0 \\
\hline
\end{tabular}


1. ábra: A pályaválasztáshoz kapcsolódó nébány kifejezés gyakorisága. Forrás: a Szerző

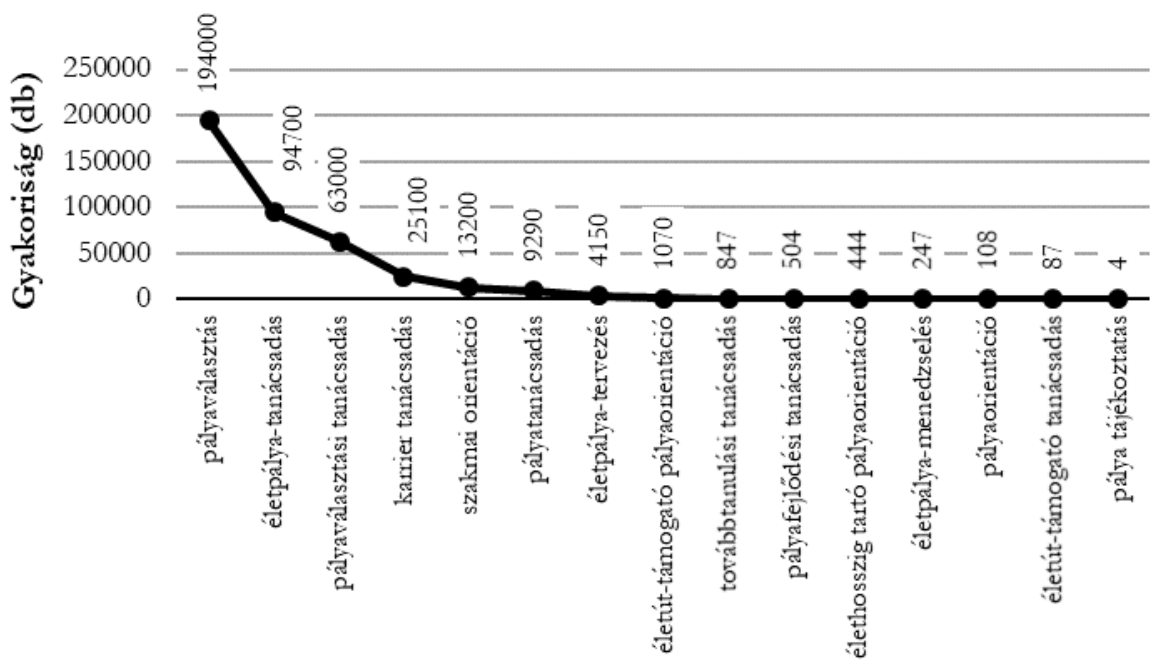

A Google keresőmotorja által talált kifejezések 2021.10.10.-én

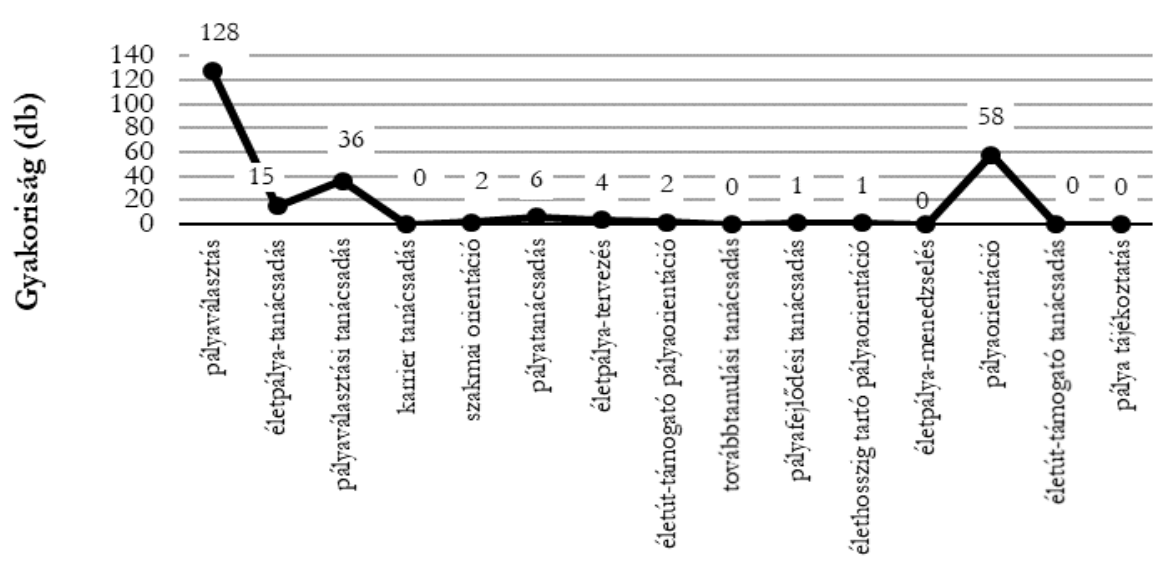

A Magyar folyóiratok tartalomjegyzékeinek kereshető adatbázisában (MATARKA) keresett kifejezések (az 18002021.10.10. között megjelent folyóiratok címében)

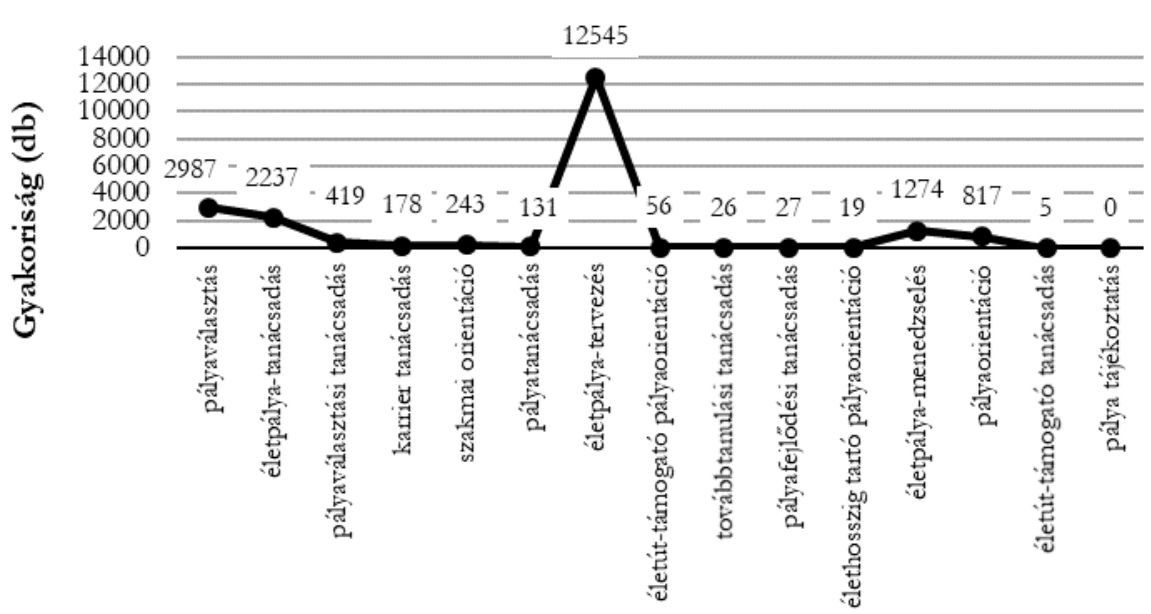

Az Elektronikus Periodika Archívumban (EPA) keresett kifejezések (az adatbázis teljes szövegében, 1703-2021.10.10-ig közöttmegjelent múvek esetében) 
Az eltérő találati értékek mögött húzódó lehetséges (egymást nem kizáró) okok:

a) Egy-egy fogalom elterjedését nagy mértékben befolyásolhatja, hogy milyen régóta van használatban. Az 1. táblázatban találhatók közül a „pályaválasztás” a leggyakoribb és egyben a legkorábban született kifejezés is. 1926-ban már „Tehetségvédelem és pályaválasztás" címmel rendeztek kongresszust (Zakar, 2016). Ehhez képest a „pályaorientáció” kifejezés a rendszerváltást követően, az 1990-es években kezdett elterjedni a hazai szóhasználatban. A pályaorientáció célcsoportjának akkoriban még csak az iskolás korosztályt tekintették, ám az egyszeri pályaválasztás helyett a pályaválasztást folyamatnak kezdték tekinteni, mivel az élet során többször lehet pályaválasztási döntést hozni; ráadásul: nem választani, hanem tájékoztatni (orientálni) kell. E fogalom 2008-ban némi változáson esett át, amikor az Európa Tanács a felnőttkorra is kiterjesztette a pályaorientáció célcsoportját (lásd az ELGPN Szakszótár magyar fordítását: Jackson, 2013) és a tájékoztatáson túl a tanácsadást, tanítást, értékelést és érdekképviseletet is e fogalom alá rendelte.

b) Egy szakekifejezés idézettségére hatással lehet, hogy bekerül-e jogi, szakpolitikai dokumentumokba (tekintve, hogy például az adott jogi dokumentum hatálya alá eső szervezetek, személyek az adott fogalmat használni „kénytelenek”). Példa: a pályaválasztási tanácsadás 1959-ben jelent meg először - a 1024/1959 (VII.19.) - kormányhatározatban. Az 1993. évi LXXIX. törvény a közoktatásról még mindig a „pályaválasztás” fogalmat használja, a „pályaorientáció”-t nem említi (holott az az 1990-es évek elejétől már megjelent a szaknyelvben). A nemzeti köznevelésrôl szóló 2011. évi CXC. törvény 62.§ 1./1 bekezdése azonban már a „pályaorientáció”-t jelöli meg a pedagógusok kötelességei egyikeként.

c) Egy szakekifejezés elófordulási gyakoriságát befolyásolhatja az is, hogy bekerül-e egy könyv vagy folyoirat címébe. Könyvcímre példa: Mérei Ferenc (1942) „A pályaválasztás lélektana" címú mûve. A Miskolci Egyetem 2009-2015 között megjelent folyóiratának pedig „Életpálya-tanácsadás” volt a címe.

A fogalmak közötti tájékozódást nehezíti, hogy olykor egymás szinonimájaként, olykor egymástól élesen elkülönülő fogalmakként kezeli azokat a szakirodalom. Nem könnyíti meg a tájékozódást az sem, ha angol nyelvből van lefordítva egy fogalom (lifelong guidance: élethosszig tartó tanácsadás), aminek azonban magyar elnevezésként az „életpálya-tanácsadás" terjedt el. Sokat segíthetne a fogalmak rendszerezésében egy pályaválasztási szakszótár, fogalomtár - amilyenre példa lehet a Jackson (2013) által szerkesztett Európai Pályaorientációs Szakpolitikai Hálózat szakszótár, vagy a már említtet „Életpálya-Tanácsadás” folyóirat hasábjain egykor közzétett fogalomtár. Egyenlőre olyan szakszótárral nem találkozhatunk, ami az 1. táblázatban közölt fogalmakat egyaránt közli, összeveti (hozzátéve, hogy még az említett táblázatban szereplő fogalmakon túl is lehetnek ide vágó szakkifejezések).

E tanulmány további részében egy lehetséges rendezési elvet vetünk fel, ami a jelzett fogalmi káoszt szándéka szerint orvosolni próbálja.

\section{Szóösszetételekből \\ kiinduló fogalomrendszer}

Az 1. táblázatban közölt, pályaválasztással kapcsolatos kifejezések legtöbbje 2-3 szó összetételéből áll, és szerkezetük jellemzően a

kifejezés $=$ téma + segító tevékenység

séma szerint alakul (2. táblázat).

Amint az a 2. táblázatban látható, a kifejezések első szemantikai egysége jelöli ki azt a témát (például: „életpálya”, „pálya-,, „továbbtanulás”, stb.), amire a második részben megadott segító tevékenység (ami lehet „tájékoztatás”, „menedzselés”, „tervezés” stb.) vonatkozik.

Mindez azzal az elônnyel jár, hogy amennyiben megtudjuk határozni a gyakori témákat, valamint a segítő tevékenységeket, akkor azok bármilyen kombinációját elő tudjuk állítani (lásd. 3. táblázat). Például: tegyük fel, hogy a „továbbtanulási tanácsadás” kifejezésben a „továbbtanulás(i)” témát röviden így határozzuk meg: „Egy személy számára már meglévő (vagy hamarosan meglévő) tanulmányi végzettséget követő képzési lehetôségre vonatkozó,...". 


\section{2. táblázat: Példák a „téma + segito" tevékenység” sémán alapuló kifejezésekre. Forrás: a Szerzō"}

\begin{tabular}{|c|c|c|c|}
\hline Kifejezés* & Téma & + & Segítő tevékenység \\
\hline élethosszig tartó pályaorientáció & élethosszig tartó pálya- & & orientáció \\
\hline életpálva-menedzselés & életpálva & & menedzselés \\
\hline életpálya-tanácsadás & életpálya & & tanácsadás \\
\hline életpálya-tervezés & életpálya & & tervezés \\
\hline életút-támogató pályaorientáció & életút-támogató & & orientáció \\
\hline életút-támogató tanácsadás & életút-támogató & & tanácsadás \\
\hline karrier tanácsadás & karrier & & tanácsadás \\
\hline pályafejlődési tanácsadás & pályafejlődési & & tanácsadás \\
\hline pályaorientáció & pálya- & & orientáció \\
\hline pályatájékoztatás & pálya- & & tájékoztatás \\
\hline pályatanácsadás & pálya- & & tanácsadás \\
\hline pályaválasztás & pálya- & & választás \\
\hline pályaválasztási tanácsadás & pályaválasztás(i) & & tanácsadás \\
\hline szakmai orientáció & szakmai & & orientáció \\
\hline továbbtanulási tanácsadás & továbbtanulás(i) & & tanácsadás \\
\hline
\end{tabular}

\section{*ABC-rendben felsorolva}

Másrészt a segítő tevékenységként megjelölhető „tanácsadás”-t pedig röviden így írjuk körül: „....egy másik személy (a tanácsadó) által segített döntéshozatal". A témára vonatkozó mondatkezdő, valamint a segító tevékenységre utaló mondatzáró szövegrészeknek egyetlen összetett mondatba szerkesztéseként kapjuk meg végeredményként a „továbbtanulási tanácsadás” következő rövid, egyértelmúsítő meghatározását: „Egy személy számára már meglévő (vagy hamarosan meglévő) tanulmányi végzettséget követő képzési lehetőségre vonatkozó, egy másik személy (a tanácsadó) által segített döntéshozatal".

Azonban, ha a „továbbtanulási tanácsadás” helyett a „pályaválasztási tanácsadás” egyértelműsítő rövid meghatározására van szükség, akkor mindössze a témaként értelmezhető „továbbtanulás(i)” szót szükséges „pályaválasztás(i)” szóra cserélnünk, illetve ez utóbbihoz tartozó tömör körülírást („Egy személy életének egészében, de legalább jelentôs részében végzett szakma kiválasztására vonatkozó,..." szükséges a meghatározás témát definiáló egységében alkalmaznunk. A segítő tevékenység leírása e-közben változatlan marad, hiszen témától füg-getlen módon kezelhetjük a „tanácsadás”-t. A „pályaválasztási tanácsadás” egyértelmúsítő körülírása így a következő lehet: „Egy személy életének egészében, de legalább jelentős részében végzett szakma kiválasztására vonatkozó, egy másik személy (a tanácsadó) által segített döntéshozatal”.

Noha az így kapott meghatározások valószínúleg nem felelnek meg a témába vágó minden valaha kiadott publikáció szó- és fogalomhasználatának, azonban arra kiválóan alkalmasak, hogy legalább átfogó képet adjanak a pályaválasztással kapcsolatos kifejezések egy jelentôs részérôl (a 3. táblázatban látható példában: 4 téma x 4 segítô tevékenység = 16 lehetséges fogalomról), egyértelmúsítsék azokat. Hangsúlyozni kell, hogy a 3. táblázatban lévő tartalmakat (a témákát és a témákra vonatkozó körülírásokat, illetve a segító tevékenységeket és a rájuk vonatkozó tömör meghatározásokat) példának szánjuk. Ezektól adott esetben el lehet térni, ám a téma és a segítő tevékenység adott kutatásban, publikációban alkalmazott meghatározását mindenképpen célszerű közölni. 
3. táblázat: Példák (amiktöl szü̈eség esetén el lehet térni) a „téma + segitô tevékenység” séma alkalmazására a pályaválasżtással keapcsolatos nébány kifejezés esetében. Forrás: a Szerzoo"

\begin{tabular}{|c|c|c|c|c|}
\hline \multirow[b]{2}{*}{ TÉMA } & \multicolumn{4}{|c|}{ SEGÍTŐ TEVÉKENYSÉG* } \\
\hline & $\begin{array}{l}\text { TÁJÉKOZTATÁS: } \\
\text { tényszerú információk } \\
\text { biztosítása }\end{array}$ & $\begin{array}{l}\text { TANÁCSADÁS: } \\
\text { egy másik személy } \\
\text { (a tanácsadó) által } \\
\text { segített döntéshoza- } \\
\text { tal }\end{array}$ & $\begin{array}{l}\text { TERVEZÉS: } \\
\text { adott cél elérését biz- } \\
\text { tosító tevékenységek } \\
\text { meghatározása }\end{array}$ & $\begin{array}{l}\text { MENEDZSELÉS: } \\
\text { adott cél elérését segítő in- } \\
\text { tézkedések megvalósítása } \\
\text { egy másik személy (a mene- } \\
\text { dzser) által koordinált mó- } \\
\text { don }\end{array}$ \\
\hline $\begin{array}{l}\text { TOVÁBBTANULÁS(I): } \\
\text { egy személy számára mát } \\
\text { meglévö (vagy hamarosan } \\
\text { meglévö) tanulmányi vég- } \\
\text { zettséget követő képzési le- } \\
\text { hetőségre vonatkozó... }\end{array}$ & $\begin{array}{l}\text { Egy személy számára már } \\
\text { meglévö (vagy hamarosan } \\
\text { meglévö) tanulmányi végzett- } \\
\text { séget követô képzési lehetō- } \\
\text { ségre vonatkozó tényszerū } \\
\text { információk biztosítása }\end{array}$ & $\begin{array}{l}\text { Egy személy számára } \\
\text { már meglévó (vagy hama- } \\
\text { rosan meglévó) tanulmá- } \\
\text { nyi végzettséget követó } \\
\text { képzési lehetöségre vonat- } \\
\text { kozó, egy másik sze- } \\
\text { mély (a tanácsadó) } \\
\text { által segített döntés- } \\
\text { hozatal }\end{array}$ & $\begin{array}{l}\text { Egy személy számára már } \\
\text { meglévö (vagy hamarosan } \\
\text { meglévö) tanulmányi végzett- } \\
\text { séget követö képzési lehetó- } \\
\text { ségre vonatkozó cél elé- } \\
\text { rését biztosító tevékeny- } \\
\text { ségek meghatározása }\end{array}$ & $\begin{array}{l}\text { Egy személy számára már meglévố } \\
\text { (vagy hamarosan meglévö) tanul- } \\
\text { mányi végzettséget követố kép zési } \\
\text { lehetöségre vonatkozó cél elérését } \\
\text { segítő intézkedések megvalósí- } \\
\text { tása egy másik személy (a } \\
\text { menedzser) által koordinált } \\
\text { módon }\end{array}$ \\
\hline $\begin{array}{l}\text { PÁLYAVÁLASZTÁSI(I): } \\
\text { egy személy életének egé- } \\
\text { szében, de legalább jelentős } \\
\text { részében végzett szakma } \\
\text { kiválasztására vonatkozó... }\end{array}$ & $\begin{array}{l}\text { Egy személy életének egészé- } \\
\text { ben, de legalább jelentōs } \\
\text { részében végzett sqakma } \\
\text { kiválasztására vonatkozó } \\
\text { tényszerū információk } \\
\text { biztosítása }\end{array}$ & $\begin{array}{l}\text { Egy személy életének egé- } \\
\text { szében, de legalább jelen- } \\
\text { tốs részében végzett szak- } \\
\text { ma kiválasztására vonat- } \\
\text { kozó, egy másik sze- } \\
\text { mély (a tanácsadó) } \\
\text { által segített döntés- } \\
\text { hozatal }\end{array}$ & $\begin{array}{l}\text { Egy személy életének egészé- } \\
\text { ben, de legalább jelentós } \\
\text { részében végzett szakma } \\
\text { kiválasztására vonatkozó } \\
\text { cél elérését biztosító } \\
\text { tevékenységek meghatá- } \\
\text { rozása }\end{array}$ & $\begin{array}{l}\text { Egy személy életének egészében, de } \\
\text { legalább jelentös részében végzett } \\
\text { szakma kiválasztására vonatkozó } \\
\text { cél elérését segitő intézkedések } \\
\text { megvalósítása egy másik sze- } \\
\text { mély (a menedzser) által koor- } \\
\text { dinált módon }\end{array}$ \\
\hline $\begin{array}{l}\text { PÁLYA-: } \\
\text { egy személy életének egé- } \\
\text { szében, de legalább jelen- } \\
\text { tôs részében végzett szak- } \\
\text { mára vonatkozó... }\end{array}$ & $\begin{array}{l}\text { Egy sqemély életének egészée } \\
\text { ben, de legalább jelentốs } \\
\text { részében végzett szakmára } \\
\text { vonatkozó tényszerű in- } \\
\text { formációk biztosítása }\end{array}$ & $\begin{array}{l}\text { Egy személy életének } \\
\text { egészében, de legalább je- } \\
\text { lentös részében végzett } \\
\text { szakemára vonatkozó, } \\
\text { egy másik személy (a } \\
\text { tanácsadó) által segí- } \\
\text { tett döntéshozatal }\end{array}$ & $\begin{array}{l}\text { Egy személy életének } \\
\text { egészében, de legalább jelen- } \\
\text { tôs részében végzett szakmá- } \\
\text { ra vonatkozó cél elérését } \\
\text { biztosító tevékenységek } \\
\text { meghatározása }\end{array}$ & $\begin{array}{l}\text { Egy személy életének egészében, de } \\
\text { legalább jelentôs részében végzett } \\
\text { szakmára vonatkozó cél elérését } \\
\text { segítő intézkedések megvalósí- } \\
\text { tása egy másik személy (a me- } \\
\text { nedzser) által koordinált mó- } \\
\text { don }\end{array}$ \\
\hline $\begin{array}{l}\text { KARRIER: egy tágabb } \\
\text { értelemben vett szakma, } \\
\text { vagy egy szükebb érte- } \\
\text { lemben vett munkahely } \\
\text { szervezeti hierarchiájában } \\
\text { történö elöre jutásra } \\
\text { vonatkozó... }\end{array}$ & $\begin{array}{l}\text { Egy tágabb értelemben vett } \\
\text { szakma, vagy egy szükebb } \\
\text { értelemben vett munkabely } \\
\text { szervezeti bierarchiájában } \\
\text { történó elöre jutásra vonat- } \\
\text { kozó tényszerű informá- } \\
\text { ciók biztosítása }\end{array}$ & $\begin{array}{l}\text { Egy tágabb értelemben } \\
\text { vett szakma, vagy egy } \\
\text { sqükeebb értelemben vett } \\
\text { munkabely szervezeti bie- } \\
\text { rarchiájában történó elöre } \\
\text { jutásra vonatkozó, egy } \\
\text { másik személy (a ta- } \\
\text { nácsadó) által segített } \\
\text { döntéshozatal }\end{array}$ & $\begin{array}{l}\text { Egy tágabb értelemben vett } \\
\text { szakma, vagy egy sqükeebb } \\
\text { értelemben vett munkabely } \\
\text { szervezeti bierarchiájában } \\
\text { történó elóre jutásra vonat- } \\
\text { kozó cél elérését bizto- } \\
\text { sító tevékenységek meg- } \\
\text { határozása }\end{array}$ & $\begin{array}{l}\text { Egy tágabb értelemben vett szakma, } \\
\text { vagy egy szükebb értelemben vett } \\
\text { munkahely szervezeti bierarchiá- } \\
\text { jában történố elóre jutásra vonat- } \\
\text { kozó cél elérését segítô intézke- } \\
\text { dések megvalósítása egy másik } \\
\text { személy (a menedzser) által } \\
\text { koordinált módon }\end{array}$ \\
\hline
\end{tabular}

*E segítő tevékenység átfogó neve a 14-18 éves korosztály esetében: pályaorientáció, minden korosztály esetében: életpályatanácsadás (Lifelong Guidance).

\section{Témák}

A pályaválasztással kapcsolatos segítő tevékenység jellegzetes témakörei a következők (v.ö. 1., 2. és 3. táblázat).

Pálya. Az önmagában, illetve szóösszetétel vagy, több szóból álló kifejezés részeként leggyakrabban említett témakör: a „pálya”. Előfordul például olyan kifejezésekben mint: pályaválasztás, életpálya-tanácsadás, pályaválasztási tanácsadás, pályatanácsadás, életpálya-tervezés, életút-támogató pályaorientáció, pályafejlődési tanácsadás, élethosszig tartó pályaorientáció, életpálya-menedzselés, pálya- orientáció, pálya tájékoztatás. E kifejezések együttes előfordulási gyakorisága (v.ö.: 1. táblázat): a Google esetében összesen 406751 találatból 367517 db (90,35\%) találat tartalmazta a „pálya” részletet, a MATARKA adatbázisban a megjelent tanulmányok címében 253 találatból 251 db (99,21\%) találat, az EPA esetében pedig 20964 találatból 20512 db (97,84\%) találatról van szó. A „pálya” kifejezés már a XX. század elején bizonyíthatóan használatban volt Magyarországon (lásd: a fent említett 1926-os „Tehetségvédelem és pályaválasztás" kongresszust - Zakar, 2016), és napjaink szóhasználatának is visszatérô eleme. 
A „pálya” metafora fizikai és közlekedési aspektusból is értelmezhető módon fejezi ki azt a szemléletet, hogy egy adott szakma választását (lényegében a pályaválasztást) követheti a szakma „irányába” történő elindulás (a pályakezdés, pályára állás), amit a szakma gyakorlása (pályán maradás, maga a pálya) vagy elhagyása (pályaelhagyás) követheti. A „pálya” szemléletes szókép felidéz bennünk egy előre kijelölt konkrét útvonalat, ami alapján a szakmai karrier átvitt értelemben vett útvonalát is könnyebb elképzelni. Ez lehetőséget ad a fizikai természetű pályával, úttal kapcsolatos kifejezések (például egyenes, kacskaringós, kanyargós, rövid út, hosszú út, döcögős út, stb.) összevetésére az átvitt értelembe vett „pálya” szóval. Ennek eredményeként átvitt értelemben is jelentése van a „kacskaringós pályája” van, „egyenes út vezetett a jelenlegi beosztásáig", stb. kifejezéseknek. Továbbá tágabb értelemben az „életút” és „életpálya” kontextusban is használjuk e fogalmat.

A rendszerváltás előtti időszakra jellemzően az „1 élet : 1 pálya" személet volt jellemző: a pályaválasztást az iskolás korosztályt érintő, egyszeri, ireverzibilis, megváltoztathatatlan, az egyén életében nagy jelentőségű döntésnek tekintették (BorbélyPecze és tsai, 2020).

A rendszerváltást követően kezdett egyre nagyobb teret hódítani az „1 élet : több pálya” szemlélet, ami a pályaválasztást már a felnőttkorra is kiterjeszti, nem egyszeri, reverzibilis, nem megváltoztathatatlan, bár továbbra is nagy jelentőségü esemény(ek)nek tekinti egy személy életében.

Meg kell jegyeznünk, hogy az „élet : pálya” arányt tekintve a felsoroltakon kívül még egy jellegzetes esettel is találkozhatunk: az „1 élet : 0 pálya” aránnyal, ami lényegében a pályaválasztás lehetetlenné válásakor (például a munkavégzést lehetetlenné tevő veleszületett vagy szerzett fogyatékosság esetében) jön létre, vagy más esetben éppen a pályaválasztás kudarcának tekinthető (2. ábra). A 2. ábrán az „1 élet : 0 pálya” arány 1.1. és 1.2. esetei a sajátos nevelési igényú gyermekek, tanulók, illetve a megváltozott munkaképességű emberek pályaválasztási problémáira hívják fel a figyelmet (Tudlik, 2019, Molnár és Mező, 2021). Hangsúlyozni szükséges, hogy a különleges bánásmódot igénylő tehetséges gyermekeknek szintén jelentős pályaválasztási problémái lehetnek, bár természetesen más természetűek, ahogyan a kettős különlegességű (például egyszerre sajátos nevelési igényű és tehetséges) tanulóknak is (lásd: Mező, 2015), miként az iskolai lemorzsolódással erősen fenyegetett hátrányos helyzetű (akár: hátrányos helyzetű és tehetséges) tanulóknak is (Hanák, 2016).

A pályaválasztás az iskoláskorú népességben szűkebb értelemben a továbbtanulási döntés meghozataláról szól: így jellemző téma a „továbbtanulás” is.

Továbbtanulás(i): „egy személy számára már meglévő (vagy hamarosan meglévő) tanulmányi végzettséget követô képzési lehetőségre vonatkozó ...” mondatrészt helyettesítő, rövidítő kifejezésként szerepel a 3. táblázatban. A ,továbbtanulás” kérdésköre az ,iskolaválasztással” részben rokon kifejezés. Azonban amíg az ,iskolaválasztás” konkrét intézmények közötti választásra utal, addig a „továbbtanulás” kifejezés kevésbé intézményspecifikus jellegű, s inkább a tanulási szándékot fejezi ki egy következő lehetséges szinten. A továbbtanulással kapcsolatban a tanulókban felmerülő jellemző kérdések például:, „Mit tanuljak?”, „Melyik intézményben, tagozaton, stb. tanuljak tovább?”, „Hol találok információt a továbbtanulási lehetőségekről?”, „Hol találok információt a jelentkezés módjáról, feltételeiről?”, „Hogyan kell használni a továbbtanulási tájékoztatót?" stb.

E kérdések lényegében azonosak a tanulást információfeldolgozó folyamatnak tekintő OxIPOmodell (Mező és Mező, 2019) input fázisában megjelenő három tanulás módszertani kérdéskörével: a témaválasztás, az információforrás kutatá-sának, az információforrás felhasználásának problémakörével. Ugyanakkor a „Képes vagyok továbbtanulni?”, „Eléggé motivált vagyok a továbbtanulásra?” típusú kérdések pedig az OxIPO-modell képesség- és motiváció-metaváltozóihoz (valamennyi tanulásváltozó esetében értelmezhető jellemzőkhöz) kapcsolódik. Ennek követ-keztében az OxIPO-sémán alapuló tanulás módszertani fejlesztés során a továbbtanulási döntés megalapozásához szükséges metodikák is átadhatók a résztvevőknek. 
2. ábra: Példák az élet:pálya arány alakulására és jellegzetes eseteire. Forrás: a Szuerző

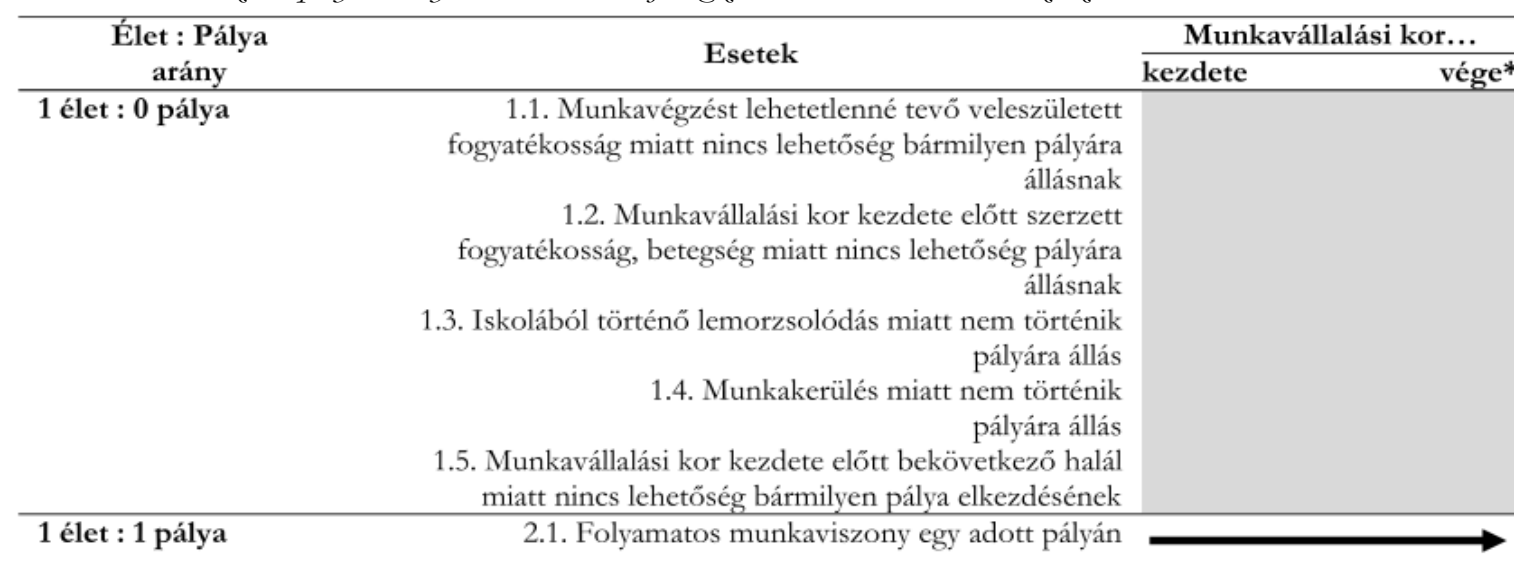

2.2. Egy adott pályán maradás ideiglenes munkaviszony megszakítással***

2.3. Többször megszakított munkaviszony egy adott pályán

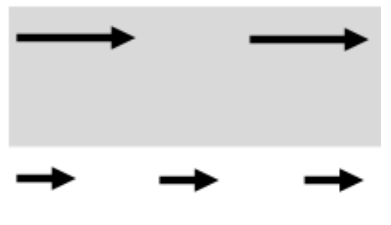

2.4. Pályakezdés, majd tartós munkanélkülivé válás

\section{1 élet : több pálya}

3.1. Párhuzamos pályák

3.1. Pályamódosítás

3.3. Kitérés, majd pályafolytatás
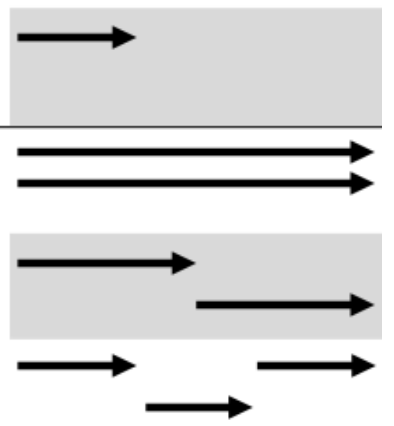

3.4. Összetett életpálya

(Az ábrán látható példa: egy pálya elkezdése után pályamódosítás egy másik pályára, arról egy harmadikra, majd egy ideid a 2. és a 3. pálya párhuzamos folytatása, végül csak a 2. pályán töltött idô jellemzi munkavállalási kor végéig tartó

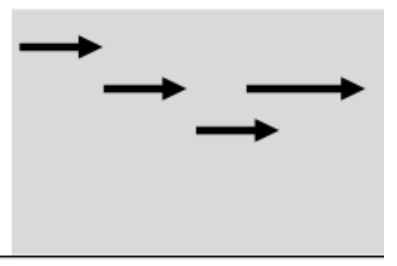

\footnotetext{
*Vagy: munkavállalási kor vége előtt bekövetkező elhalálozás
}

idổszakot.)

** Ennek oka lehet: gyermek születése, utazás, betegség, munkahely megszünése, munkaviszony megszűntetése

Egy utolsó jellegzetes példaként szerepeljen itt a „karrier”, mint a pályaválasztáshoz kapcsolódó segítő tevékenységek egy lehetséges fókusza.

Karrier: „egy tágabb értelemben vett szakma, vagy egy szúkebb értelemben vett munkahely szervezeti hierarchiájában történő előre jutásra vonatkozó...” szó (idézet a 3. táblázatból). Az iménti meghatározásból már látható, hogy karrierről azokon a munkahelyeken, azokban a szakmákban beszélhetünk, amelyek esetében létezik valamilyen pozícióhoz kötött (elóléptetések révén elérhetô) rangsor. 
A „karrier” szó a „szekér” jelentésű latin carrum vagy carrus, illetve a szállításra vonatkozó carier szavakra vezethető vissza. A francia a carriére már pálya, pályafutás, gyors lovas vágta jelentéssel bír. A „karrier” szó tehát a szakmai életúton való (akár: gyors) előre jutást a versenypályán vágtató paripával kifejező képes beszéd.

A karrierrel kapcsolatban felemerülő jellegzetes kérdések többek között:

- „Milyen előmeneteli rendszer létezik az adott szakmában/munkahelyen?"

- „Mi jellemzi az előmeneteli rendszer egyes állomásait?"

- „Milyen feltételeket kell teljesíteni azok elérése érdekében?"

- „Milyen előnyökkel/hátrányokkal jár az előmenetel?"

- „Milyen időbeli jellemzői vannak az egyes állomások elérésének?"

- „Mi történik, ha nem sikerül időben teljesíteni az egyes állomáshoz történő továbbjutás feltételét?"

- „Képes vagyok-e az elvárásoknak megfelelni?”
Az Európai Pályaorientációs Szakpolitikai Hálózat szakszótára (ELGPN szakszótár - Jackson, 2013, 13. o.) megfogalmazásában némileg más szemlé-lettel találkozunk: „Életpálya (Career): egy személy életén átívelő munkahelyi szerepek és egyéb élet-szerepek egymásra gyakorolt hatása, beleértve, hogy az adott személy miként találja meg az egyen-súlyt a fizetett és fizetetlen munkafeladatai között, valamint mennyi időt és energiát szán tanulásra és továbbképzésre."

A kommunikációt az is nehezíti, hogy egy-egy fogalomnak több különböző meghatározása is ismert, és nincs arra garancia, hogy minden kommunikáló fél éppen azt a fogalom meghatározást ismeri, amit társuk használ (lásd: 4. táblázat). Ennek következménye pedig egymás félreértése lehet.

A témákkal kapcsolatos fogalmak egyértelmüsítése szempontjából a későbbi teoretikus kutatások során célszerű lesz figyelmet fordítani egyrészt a szinonim kifejezések azonosítására, másrészt a fogalmak közötti hierarchia megállapítására - oly módon, hogy a már publikált fogalmi rendszereknek ne mondjon ellent e struktúra.

4. táblázat: A magyarul „életpályának” forditott „Career” meghatározása. Forrás: Jackson (2013. 13. o.) alapján a Szerzo"

Szerző Meghatározás

Arthur és tsai (1989) Egy személy munkatapasztalatainak idővel fejlődő sorozata.

Arnold (1997)

Hansen és Gysbers (1975) Az életpálya általában véve életszerepekre és életmódra összpontosít, míg egy

Watts (1998)

A szinonim kifejezések létének következménye, hogy azok szabadon felcserélhetők egymással akár foglalkozás az életpálya csak egy részének tekinthető.

Az életpálya a foglalkoztatással kapcsolatos pozíciók, szerepek, tevékenységek és tapasztalatok sorozata egy személy életében.

Egy egyén élethosszig tartó előmenetele a tanulás és munka területén 
különösen, ha a köz- és szaknyelvet használók körében egyaránt közismert, hogy e kifejezések valójában ugyanarra a tartalomra utalnak. Azonban: hiába rokon értelműek e kifejezések, ha a szinonim-jellegükre vonatkozó közismeret valójában nem biztosított. Ergo: a fogalmak tisztázása mellett (inkább: azt követôen) társadalmi szemléletformálásra van szükség, valamint a szúkebb értelemben vett pályaorientációs szakemberképzésben, valamint a pedagógusképzésben, -továbbképzésben is meg kell jelennie e tartalmaknak.

A fent említett ELGPN szakszótár (Jackson, 2013, 26. o.) szerint például szinonimaként kezelhetők az alábbiak: a szakmai tanácsadás (vocational guidance) szinonimájának is tekinthető pályaorientáció (career guidance) „meghatározása megegyezik az élethosszig tartó pályaorientáció (lifelong guidance) definíciójával." Ezzel összefüggésben pedig az élethosszig tartó pályaorientáció (lifelong guidace): „Olyan tevékenységek összessége, amelyek bármilyen korosztályhoz tartozó állampolgárok számára, életük bármely pontján lehetővé teszik, hogy felmérjék képességeiket, kompetenciáikat és érdeklődésüket; hogy észszerű oktatási, képzési és foglalkoztatási döntéseket hozzanak; valamint, hogy menedzselni tudják egyéni életútjukat a tanulás, munka és egyéb olyan területeken, ahol ezeket a képességeket és kompetenciákat sajátíthatják el vagy használhatják" (Jackson, 2013, 12. o.).

A szinonim kifejezések számát gyarapítják az idegen nyelvű szóhasználatból szó szerint, illetve tartalmi szinten magyar nyelvre fordított kifejezések is.

A pályaorientációval kapcsolatos fogalmak közötti bierarchikus viszony tisztázásának kommunikációs következménye pedig az, hogy a fogalmi hierarchia magasabb szintjét álló fogalom említésekor az alárendelt fogalmaknak és az azokkal kapcsolatos háttérismereteknek is tudatában kell lennie a kommunikáló feleknek. Vagy: a félreértéseket minimalizálni törekvő köz- és szaknyelvi kommunikáció kapcsán a feleknek minden alárendelt fogalom esetében tudniuk szükséges, hogy milyen fö-fogalom, illetve fölérendelt fogalom körébe tartoznak, s természetesen, hogy vannak e további alárendelt fogalmaik, valamint milyen mellérendelt fogalmak tartoznak még a már említett fölérendelt fogalom körébe. A fogalmak közötti hierarchia az iméntihez hasonlító körülírása igen zavaros, nehézkes, ám a fogalmak ágrajzszerű vizualizációja, vagy egyszerű decimális fejezetszámozás szerinti felsorolása már segítheti a fogalmak közötti hierarchikus viszonyok megértését.

Például: néhány fogalom között egyértelmű hierarchikus viszonyt is megfogalmaz az ELGPN szakszótár (Jackson, 2013, 26. o.):

„A pályaorientáció (guidance) valójában egy ernyőfogalom, amely magában foglalja nem csak a tanácsadást (counselling), de olyan tevékenységeket is, mint a tájékoztatás, coaching, tanítás, értékelés és érdekképviselet."

Az idézett fogalmi hierarchia (az alá-, fölé-, mellérendelő viszonyt vizuálisan is szemléltető) ágrajzzal, illetve decimális fejezetszámozással jelölt reprezentációját szolgálja a 3. ábra. E felsorolás elemei azonban már a segítőtevékenységekre vonatkoznak.

\section{A segítő tevékenységek}

A pályaválasztás tág témakörét érintő segítő tevékenységek meghatározása és egymással való kapcsolata is elősegítheti egy egységes fogalmi rendszer kialakítását. A megértést segítő fogalmi lehatárolás érdekében - a szinonimák és a fogalmi alá-, fölé- és mellé-rendelődő viszonyok tisztázása mellett - arra is szükség van, hogy rámutassunk miben különbözik a segítő tevékenységek egyike a többitől. Az alábbiakban - a teljesség igénye nélkül, mindössze problémafelvetés jelleggel - erre mutatunk egy példát. Az 1. ábrán is szereplő jellegzetes segítő tevékenységek közötti fogalmi és egyben tényleges tevékenységbeli különbségeket szemlélteti a 4. ábra. 
3. ábra: A pályaorientáció, mint fó-fogalom és alárendelt fogalmai az Európai Pályaorientációs Szakpolitikai Hálózat szakeszótár szerint ágrajzzal és decimális fejezetszámozással szemléltetve (Jackson, 2013, 26. o. alapján a Szerzó)

A fogalmi hierarchia szemléltetése ágrajzzal:

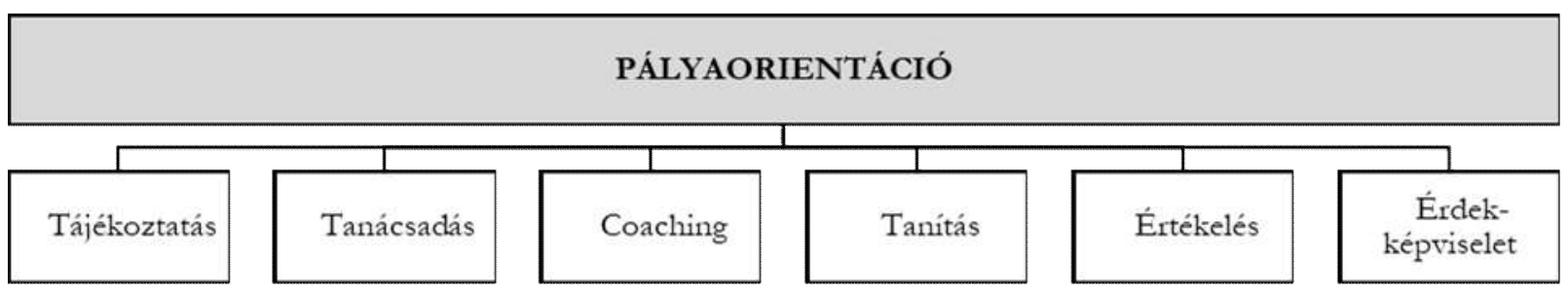

A fogalmi hierarchia kifejezése decimális fejezetszámozással:

\section{Pályaorientáció}

1.1. Tájékoztatás

1.2. Tanácsadás

1.3. Coaching

1.4. Tanítás

1.5. Értékelés

1.6. Érdekképviselet

4. ábra: Segitö tevékenységek közötti különbség. Forrás: a Szerző

\begin{tabular}{|c|c|c|c|c|c|c|}
\hline \multirow{2}{*}{\multicolumn{2}{|c|}{$\begin{array}{l}\text { Tevékenység } \\
\text { átfogó } \\
\text { megnevezése, } \\
\text { ha a célcsoport: }\end{array}$}} & \multirow[b]{3}{*}{$\begin{array}{c}\text { Segítő } \\
\text { tevékenység } \\
\text { megnevezése }\end{array}$} & \multicolumn{4}{|c|}{ Jellemző feladatok } \\
\hline & & & \multirow[b]{2}{*}{$\begin{array}{l}\text { Információ } \\
\text { átadás }\end{array}$} & \multirow[b]{2}{*}{$\begin{array}{c}\text { Döntéshozatal } \\
\text { az } \\
\text { információk } \\
\text { alapján } \\
\end{array}$} & \multirow{2}{*}{$\begin{array}{c}\text { Döntés } \\
\text { megvalósításához } \\
\text { vezető } \\
\text { tevékenységek, } \\
\text { folyamatok } \\
\text { meghatározása }\end{array}$} & \multirow[b]{2}{*}{$\begin{array}{c}\text { Döntést } \\
\text { megvalósító } \\
\text { terv } \\
\text { végrehajtása }\end{array}$} \\
\hline $\begin{array}{c}14-18 \\
\text { évesek }\end{array}$ & $\begin{array}{c}\text { Minden } \\
\text { kor- } \\
\text { osztály }\end{array}$ & & & & & \\
\hline \multirow{4}{*}{ 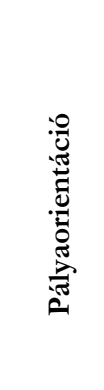 } & & Tájékoztatás & $\checkmark$ & & & \\
\hline & vi & Tanácsadás & $\checkmark$ & $\checkmark$ & & \\
\hline & 包 & Tervezés & $\checkmark$ & $\checkmark$ & $\checkmark$ & \\
\hline & 玵氙 & Menedzselés & $\checkmark$ & $\checkmark$ & $\checkmark$ & $\checkmark$ \\
\hline
\end{tabular}


A 4. ábrán szemléltetett felfogás szerint a tájékoztatás lényege a tényszerú információközlés pályaválasztással kapcsolatos kérdésekkel kapcsolatban, ám bármiféle tanács megfogalmazásának igénye nélkül.

A non-direktív vagy direktív módon is megvalósítható (nagy valószínúséggel tájékoztatást is tartalmazó) tanácsadás a döntéshozatalban segítheti kliensét. A non-direktív tanácsadás során a tanácsadó hozzásegíti a tanácsot kérô félt ahhoz, hogy saját maga „termelje” ki a döntést. A direktív tanácsadás során a tanácsadó fél dominánsabb szerepet vállal a döntés meghozatalában - szélsőséges esetben meghozza a döntést a kliens helyett, $\mathrm{s}$ javaslatot tesz annak elfogadására. De: még a direkt tanácsadás sem részletezi aprólékosan a döntésben kijelölt cél eléréséhez vezető tevékenységet, amit azonban a tervezés már megvalósít. Végül: a menedzselés már nemcsak egy eldöntött cél elérésének lépéseit taglalja, hanem megtörténik a cél eléréséhez vezetô tevékenységek megvalósítása is, mely folyamatot egy menedzsernek tekintett személy koordinál (akár úgyis, hogy több-kevesebb feladatot átvállal a menedzsmentben részesített személytőll). A segítő tevékenységek iméntihez hasonló (de nem feltétlenül ugyanilyen) egymástól történő leha-tárolása a pályaválasztás tág témakörét érintő kuta-tás, képzés és gyakorlati „terepmunka” szempont-jából is kommunikációs hatékonyságot fokozó jelentőségű lehet.

\section{Zárógondolatok}

A pályaorientációval kapcsolatos köz- és szaknyelvi kommunikációt és e kommunikáción alapuló gyakorlati, kutatási és képzési tevékenységet nehezíti a témával kapcsolatos fogalmi káosz. A fogalmak tisztázása érdekében célszerū tisztázni a pályaorientációval kapcsolatos konkrét témák és segítő tevékenységek megnevezését, ezek szinonímáit, egymástól történő elhatárolásukat, illetve ezek egymáshoz képest értelmezhető alá-, fölé- és mellérendelődő viszonyait. Erre történtek már kezdeményezések hazánkban és külföldön egyaránt, azonban máig nem sikerült maradéktalanul megvaló- sítani e gyakorlati jelentőséggel is bíró teoretikus feladatot. Célszerú lenne tehát egy szakmai plénum, szakértôi csoport által e fogalomrendszert átgondolni, megalkotni, és a véglegesnek tekintett glosszáriumot széles társadalmi, és szűkebb szakmai körökben egyaránt terjeszteni.

\section{Irodalom}

2011. évi CXC. törvény a nemreti köznevelésröl

2012. évi I. törvény a munka törvénykönyvéról

2019. évi LXXX. törvény a szakeképzésröl

Arnold, Jhonn. (1997): Managing Careers into the 21st Century. London: Paul Chapman.

Arthur, Michael B., Hall, Douglas T. \& Lawrence, Barbara S. (1989): Generating new directions in career theory: The case for a transdisciplinary approach. In Arthur, M.B., Hall, D.T. és Lawrence, B.S. (Eds): The Handbook of Career Theory. Cambridge: Cambridge University Press

Borbély-Pecze Tibor Bors (2010a): Életutt-támogató pályaorientáció, ELTE PPK, PhD értekezés, kézirat.

Borbély-Pecze Tibor Bors (szerk.) (2010b) Az életút-támogató pályaorientáció rendszerének. bevezetése Ma-gyarországon. FSZH, Budapest

Borbély-Pecze Tibor Bors, Gyöngyösi Katalin és Juhász Ágnes (2013): Az életút-támogató pályaorientáció a köznevelésben (2. rész). Pályaorientációs szakpolitika - alapelvek és javaslatok. Új Pedagógiai Szemle, 63. évf., 2013, 78. sz. 32-46.

Borbély-Pecze Tibor Bors, Suhajda Csilla Judit, Kenderfi Miklós, Tajtiné Lesó Györgyi és Juhász Ágnes (2020): Pályakonstrukció és pályaalkalmasság - Egyazon életpálya két olvasata. Új Pedagógiai Szemle, 2020/9-10, 13-33.

Hanák Zsuzsanna (2016) A korai iskolaelhagyás problematikája és a megelózés lehetöségei a magyar közoktatásban. Habilitációs értekezés, Eszterházy Károly Főiskola. doi 10.15773/EKF.HABIL.2016.004

Hansen, L. Sunny és Gysbers, Norman C. (1975): Editorial. Personnel and Guidance Journal, 53, 636. 
Hawthorn, R. (1991). Who Offers Guidance. Sheffield: Employment Department.

Jackson, Charles (Ed.)(2013): Az Európai Pályaorientációs Szakpolitikai Hálózat (ELGPN) szakszótára - ELGPN Glossary. The European Lifelong Guidance Policy Network (ELGPN), Budapest. Letöltés: 2021.10.10. Web: http://www.elgpn.eu/publications/ browse-by-language/hungarian/az-europaipalyaorientacios-szakpolitikai-halozat-elgpnszakszotara-elgpn-glossary/

Mező Ferenc és Mező Katalin (2019): Az OxIPOmodell - az interdiszciplináris kutatások egy lehetséges értelmezési kerete. OxIPO - interdiszciplináris tudományos folyóirat, 2019/1, 9-21. doi 10.35405/OXIPO.2019.1.9

Mező Katalin (2015): Pályaorientáció, pályatanácsadás tehetségeseknek. Magiszter, 13. évf. 2. sz. (2015. nyár). 57-69. Letöltés: 2021.10.08. Web: http://epa.niif.hu/03900/03976/00015/pdf/E PA03976_magiszter_2015_02_057-069.pdf

Mérei Ferenc (1942): A pályaválaştás lélektana. Unitas Kiadás, Budapest.

Molnár Alexandra és Mező Katalin (2021): Tanulásban akadályozott fiatalok jövőképének vizsgálata. Különleges Bánásmód, 7. (3). 57-67. doi 10.18458/KB.2021.3.57

Olteanu Lucián Líviusz (2015). A pályaválasztás rendszerelméleti nézőpontból. Iskolakultúra, 25. (9.), 45-55. doi 10.17543/ISKKULT .2015.9.45

Olteanu Lucián Líviusz (2019a). A pályaválasztás során fellépő döntéshozási nehézségek. OxIPO - interdiszciplináris tudományos folyoirat, 2019/1, 53-59. doi 10.35405/OXIPO.2019.1.53

Olteanu Lucián Líviusz (2019b): A család szerepe a pályaválasztásban. OxIPO - interdiszzciplináris tudományos folyóirat, 2019/4, 23-35. doi 10.35405/OXIPO.2019.4.23

Répáczki Rita (2015): Mi is az az életpálya- tanácsadás? Életpálya-tanácsadás, 2009. I. (I-II.), 6-9.

Ritoók Pálné (2006): Pályalélektan, a pályaválasztás pszichológiája. In Bagdy E. és Klein S. (Szerk): Alkalmazott pszichológia. Edge 2000 Kiadó, Budapest. 50-65.

Ritoókné Ádám Magda (2008): Pályafejlódési tanácsadás. ELTE Eötvös Kiadó, Budapest

Szatmáriné Balogh Mária (1999): Mi a „karriertanácsadás”? Munkaügyi Sžemle. 1999. XLIII.(2.), 16-17.

Tudlik Csilla (2019): Akadályozottság, sajátos nevelési igény és pályaválasztási algoritmus az IPOOmodell alapján. OxIPO-interdiszciplináris tudományos folyóirat, 2019/1, 61-73. doi 10.35405/OXIPO.2019.1.61

UNESCO (2002). Handbook of Career Counselling. Letöltés: 2021.10.14. Web: http://unesdoc. unesco.org/images/0012/001257/125740e.pdf

Watts, Anthony Gordon (1998). Reshaping Career Development for the 21 st Century. Inaugural professorial lecture, University of Derby, 8 December.

Watts, Anthony Gordon (2009): The Relationship of Career Guidance to VET. Cambridge (UK): National Institute for Careers Education and Counselling. Letöltés: 2021.10.14. Web: https://www.oecd.org/education/innovationeducation/44246616.pdf

Zachár László (2005): Pályaorientáció - korszerúen. Nemzeti Felnőttképzési Intézet, Budapest.

Zachár László (2021): A népesség munkaerôpiaci aktivitása az iskolai végzettség függvényében. $U j$ Pedagógiai Szemle, 2021/05-06, 13-36.

Zakar András (1988): Pályaválasztási elméletele. Tankönyvkiadó, Budapest.

Zakar András (2016): A pályatanácsadás jogi szabályozása. Acta Universitatis Szegediensis: Acta juridica et politica, (79. Tom.) 1-64. Fasc. 669-676. 